\title{
Factors associated with milking characteristics in dairy cows
}

\author{
D. P. Berry, ${ }^{* 1}$ B. Coughlan, $†$ B. Enright,, S. Coughlan, $\dagger$ and M. Burke \\ ${ }^{*}$ Animal \& Grassland Research and Innovation Centre, Teagasc, Moorepark, Co. Cork, Ireland \\ †rish Cattle Breeding Federation, Bandon, Co. Cork, Ireland
}

\section{ABSTRACT}

Milking characteristics, and in particular milking duration, are a known contributor to costs in dairy production systems. Results from previous studies suggest that higher-yielding animals, on average, milk for a longer duration. Culling or selection for reduced milking duration alone may, therefore, reduce milk yield. Here, we propose 2 new traits, residual milking duration (RMD) and residual milking duration including somatic cell score (RMDS). Residual milking duration is represented by the residuals from a least squares regression of milking duration on milk yield; RMDS is represented by the residuals from a least squares regression of milking duration on both milk yield and somatic cell score [i.e., logarithm (base 10) of somatic cell count]. The mathematical properties of least squares regression ensure than the residual traits are independent from the regressor variables, or, in other words, RMDS is not correlated with either milk yield or somatic cell score. Both RMD and RMDS were defined using electronically measured individual cow milking duration from 235,036 part-day milking events from 74,607 cows from 1,075 Irish dairy herds. Twentyfour percent of the variation in milking duration was explained by the multiple regression model containing both milk yield and somatic cell score. The phenotypic standard deviation of RMD and RMDS was 102.2 and $98.2 \mathrm{~s}$, respectively, suggesting large variation in milking duration independent of milk yield (and somatic cell score). The correlation of RMD and RMDS with average milk flow rate, which may also be considered a measure of milking efficiency, was -0.74 and -0.75 , respectively. Neither RMD nor RMDS was correlated with somatic cell score. However, average milk flow rate was correlated with milk yield (0.57) and milking duration (-0.38). Both RMD and RMDS are useful traits, which exhibit considerable variation and, therefore, can be used by farmers to identify phenotypically slower milking animals irrespective of milk yield (and somatic

Received September 15, 2012

Accepted May 21, 2013.

${ }^{1}$ Corresponding author: Donagh.berry@teagasc.ie cell score). However, because of the lack of a correlation between RMD and somatic cell score in the sample population used in the present study, RMD and RMDS values per milking were almost identical.

Key words: milk flow, milking duration, somatic cell count, milk yield

\section{INTRODUCTION}

Increasing herd size (Jago and Berry, 2011) has raised awareness of the importance of rapid animal throughput during the milking process. Culling of slowmilking animals can increase milking parlor throughput. As reproductive performance in most dairy cattle populations improves, greater scope exists for voluntary culling on ancillary traits such as milking speed. The contribution of milking speed to profitability in dairy production systems has already been documented (Sivarajasingam et al., 1984; Boettcher et al., 1998; Prints, 2002) as well as its influence on longevity or culling (Berry et al., 2005). Krogmeier et al. (2006) documented an impact on heifer auction price of the announced milking speed of heifers at the time of sale, reflecting further the importance of milking speed in profitable dairy production systems.

Data from electronic milk meters that routinely measure milking duration provide a valuable source of information on milking speed and other milking characteristics such as flow rate. Average milk flow (AMF) rate and maximum milk flow (MMF) rate have been proposed elsewhere as measures of milking efficiency among animals (Gray et al., 2011; Samoré et al., 2011). Milking speed has also been scored subjectively for use in genetic evaluations (Berry et al., 2004). Nonetheless, comparison of animals for milking speed is not trivial and should account for differences among animals in milk yield as well as other systematic environmental effects such as parity and lactation stage. Milk yield is known to be positively associated with milking duration (Sandrucci et al., 2007; Gray et al., 2011; Samoré et al., 2011), and both milking duration and other milking characteristics are known to vary across parities (McCarthy et al., 2007; Sandrucci et al., 2007; Walsh et al., 2007) and stages of lactation (Zwald et al., 2005; 
McCarthy et al., 2007; Sandrucci et al., 2007; Walsh et al., 2007). Evidence also exists for an association between milking characteristics and udder health (Brown et al., 1986; Grindal and Hillerton, 1991; Tančin et al., 2007); faster milking cows have, on average, inferior udder health.

The objective of this study was primarily to define 2 novel traits, residual milking duration (RMD) and residual milking duration including SCS (RMDS), which is milking duration independent of milk yield or milk yield plus SCS, respectively. Variation in these novel traits will also be quantified as well as the factors associated with these traits. Knowledge of such factors can be used in the development of a statistical model to remove systematic environmental effects from milking duration thereby facilitating a more accurate comparison of animals in an on-farm decision support tool.

\section{MATERIALS AND METHODS}

\section{Data}

Milk flow data were available from the Irish Cattle Breeding Federation (http://www.icbf.com) database on 235,036 part-day milking events from 74,607 cows in 1,075 Irish dairy herds between September 2011 and July 2012. All records were between 5 and 305 d postcalving. All animals had 2 milk-recording events per test day (i.e., a.m. and p.m.), milking duration varied from 1 to $15 \mathrm{~min}$, and total milk yield per milking (i.e., a.m. or p.m. milking) varied from 1 to $30 \mathrm{~kg}$. Herd size varied from 40 to 250 cows. All herds used electronic doit-yourself Tru-Test meters (Tru-Test Ltd., Auckland, New Zealand) in herringbone milking parlors. However, the facility to store the milking characteristic information was only used on a selection of the milk meters. Do-it-yourself milk recording represents approximately $33 \%$ of milk-recorded cows in Ireland and is increasing. The number of milking units per herd varied from 6 to 22. Information was also available on the milking order (measured by the milking row) that the animal was milked. Row milking order was recoded as early (milking row $>1$ SD earlier than the mean herd milking row), middle (milking row within $\pm 1 \mathrm{SD}$ of the mean herd milking row), and late (milking row $>1$ SD later than the mean herd milking row).

The start of each individual cow milking and end of each individual cow milking was determined, for each milking session separately, by the decision rules implemented in the Tru-Test meter. Milk flow rates were recorded every $5 \mathrm{~s}$. End of milking was determined when the AMF rate was $<0.2 \mathrm{~kg} / \mathrm{min}$ over a 10 -s period. Average milk flow rate was calculated per milking as the milk yield divided by milking duration. Maximum milk flow rate was determined based on the flow rates recorded every $5 \mathrm{~s}$, and the number of seconds to reach MMF rate was also retained. The time taken, within each milking, to reach $50 \%$ of the total milk yield for that milking was also determined. Bimodality within a milking was assumed to exist if a clear drop in the milk flow pattern existed for at least $10 \mathrm{~s}$ (followed by resumption of milk flow) within the first $120 \mathrm{~s}$ of milking, which is similar to the definition used by Dzidic et al. (2004).

Milk yield was recorded in both morning and evening milk but only 1 milk sample was taken for the quantification of milk composition, usually the evening sample; prediction equations to predict 24-h milk composition (Berry et al., 2006) were not applied in the present study. The logarithm (base 10) of SCC was used to calculate SCS, which was normally distributed.

Data were also available from the Irish Cattle Breeding Federation database on the parity and breed proportion of each animal. Parities $\geq 5$ were categorized as one group. Days postcalving at milk recording were divided into 10 classes: 5 to 30,31 to 60,61 to 90,91 to 120, 121 to 150,151 to 180,181 to 210,211 to 240,241 to 270 , and 271 to 305 DIM. Breed of animal was represented by the percentage Holstein, Friesian, Montbéliarde, Norwegian Red, Jersey, and "other" in the animal. The coefficient of heterosis and the coefficient of recombination loss were calculated for each animal as $1-\sum_{i=1}^{n} \operatorname{sire}_{i} \cdot \operatorname{dam}_{i}$ and $1-\sum_{i=1}^{n} \frac{\operatorname{sire}_{i}^{2}+\operatorname{dam}_{i}^{2}}{2}$, respectively, where $\operatorname{sire}_{i}$ and $\operatorname{dam}_{i}$ are the proportion of breed $i$ in the sire and dam, respectively.

\section{Analysis}

Milking duration (s) was normally distributed and was regressed on milk yield, across all data, using a simple least squares regression (PROC GLM; SAS Institute, 2011). The residual from the linear regression was termed RMD. Milking duration (s) was also linearly regressed on both milk yield and SCS using least squares multiple regression; the residual term in this model is hereon in referred to as RMDS. Although nonlinear regression coefficients of milking duration on both milk yield and SCS were different from zero, the proportion of the variation in milking duration explained by the multiple regression model increased by only $0.1 \%$, and the statistical significance of the association is most likely an artifact of the large data set.

Mixed models in ASReml software (Gilmour et al., 2009) were used to determine the factors associated with the range of milking characteristic traits. For the continuous traits (i.e., milking duration, RMD, RMDS, 
Table 1. Number of records (n), raw mean, and raw SD of the milking characteristics variables

\begin{tabular}{lccc}
\hline Trait & $\mathrm{n}$ & Mean & $\mathrm{SD}$ \\
\hline Milk yield (kg/milking) & 235,036 & 12.39 & 4.32 \\
Milk fat content (g/kg) & 115,169 & 42.4 & 7.9 \\
Milk protein content (g/kg) & 115,173 & 34.1 & 3.3 \\
Milk lactose content (g/kg) & 115,173 & 48.0 & 2.1 \\
SCS (log cells/mL) & 115,021 & 4.95 & 0.51 \\
Milking duration (s) & 235,036 & 384 & 116.2 \\
Residual milking duration (s) & 235,036 & 0 & 102.2 \\
Residual milking duration including SCS (s) & 115,021 & 0 & 98.2 \\
Average milk flow rate (kg/min) & 235,036 & 2.02 & 0.70 \\
Maximum milk flow rate (kg/min) & 234,764 & 4.92 & 2.46 \\
Time to maximum flow rate (s) & 234,764 & 87 & 92.0 \\
Time to achieve 50\% of milking yield (s) & 234,731 & 114 & 50.0 \\
Bimodality (yes = 1; no =0) & 235,036 & 0.16 & 0.37 \\
\hline
\end{tabular}

AMF rate, MMF rate, time to achieve $50 \%$ of milking yield, and number of seconds to reach MMF rate) a linear mixed model was used; for the binary trait bimodality, the logit of the probability of bimodality in a given lactation was modeled using a nonlinear model assuming binomially distributed errors. In all models, animal was included as a random effect. Fixed effects, treated as categorical variables, considered for inclusion in all models were herd $(\mathrm{n}=1,075)$, parity $(1,2$, 3,4 , and 5+), stage of lactation (5-30, 31-60, 61-90, 91-120, 121-150, 151-180, 181-210, 211-240, 241-270, and 271-305 d postcalving), month of test $(\mathrm{n}=11)$, milking session (a.m. or p.m.), milking rank of the cow relative to contemporaries $(<1 \mathrm{SD}, \pm 1 \mathrm{SD}$, and $>1$ $\mathrm{SD})$, heterosis coefficient $(0 \%, 0.01$ to $10 \%, 10.01$ to $20 \%, \ldots, 90.01$ to $99.99 \%$, and $100 \%$ ) and recombination loss coefficient $(0 \%, 0.01$ to $10 \%, 10.01$ to $20 \%$, . . ., 40.01 to $49.99 \%$, and $50.00 \%$ ). Proportion of each breed per animal was fitted as a continuous variable, with each breed represented by a separate effect in the model; the "other" breed category was not included in the model to avoid linear dependencies between model terms. Two-way and 3-way interactions between parity, stage of lactation, and milking session were also tested for association with the dependent variable. Least squares means for a given fixed effect were obtained at the average values for the other terms in the model.

\section{RESULTS}

The majority of cows in the study were HolsteinFriesian crossbreds. The mean Holstein and Friesian proportions of the cows were 70 and $28 \%$, respectively. The mean heterosis and recombination loss coefficients in the sample population were 10 and $4 \%$, respectively. The mean parity number was 3.30 and the average days postcalving when the milkability measures were taken was $91 \mathrm{~d}$. Raw summary statistics for the milking characteristics and other performance traits are detailed in Table 1. The mean RMD and RMDS were zero, in line with the mathematical properties of least squares regression where the mean of the residuals is zero; nonetheless, considerable variation in both RMD and RMDS was evident. The regression coefficient of milking duration on milk yield in the calculation of RMD was 12.80 ( $\mathrm{SE}=0.049)$; the regression coefficients of milking duration on milk yield and SCS in the multiple regression model to calculate RMDS were 13.64 (SE $=0.130)$ and $1.14(\mathrm{SE}=0.895)$, respectively. Therefore, in the sample population under investigation in the present study, SCS was not significantly associated with milking duration after accounting for differences in milk yield. Sixteen percent of the milking events in the present study were considered to be bimodal.

Correlations among the different milking characteristic (excluding bimodality) and milk performance traits are summarized in Table 2. Higher-yielding animals, on average, milked for a longer duration; the correlation between milk yield and milking duration was 0.48 , signifying that milk yield explained $23 \%$ of the variation in milking duration. The correlations between milking duration and milk composition were weak $(-0.12$ to 0.05). The correlation between milking duration and both residual milking duration traits was very strong. The correlation between RMD and RMDS was almost unity; rounding to 2 decimal places resulted in a correlation of 1.00. Higher-yielding animals also had greater flow rates, on average. Only a weak correlation $(-0.05)$ existed between SCS and milking duration. As expected, based on the mathematical properties of least squares regression, milk yield was not correlated with RMD and neither milk yield nor SCS was correlated with RMDS.

Factors associated with the milking characteristic traits are detailed in Table 3. Most of the effects, with the possible exception of some of the breed effects and both heterosis and recombination loss, were associated with all milking characteristic traits. Mean milk yield, 
Table 2. Pearson correlations ${ }^{1}$ between the different milking characteristics variables

\begin{tabular}{|c|c|c|c|c|c|c|c|c|c|c|c|}
\hline Trait $^{2}$ & Milk yield & Fat & PROT & LACT & SCS & $\mathrm{MD}$ & RMD & RMDS & $\mathrm{AMF}$ rate & MMF rate & Time $_{\text {max }}$ \\
\hline PROT & -0.28 & 0.26 & & & & & & & & & \\
\hline LACT & 0.11 & -0.20 & -0.18 & & & & & & & & \\
\hline MD & 0.48 & -0.02 & -0.12 & 0.05 & -0.05 & & & & & & \\
\hline RMD & 0.00 & 0.05 & 0.00 & 0.01 & 0.00 & 0.88 & & & & & \\
\hline RMDS & 0.00 & 0.05 & 0.00 & 0.00 & 0.00 & 0.90 & 1.00 & & & & \\
\hline Time $_{\max }$ & 0.21 & -0.04 & -0.07 & 0.06 & -0.05 & 0.32 & 0.25 & 0.23 & -0.04 & -0.22 & \\
\hline Time $_{50}$ & 0.50 & -0.08 & -0.16 & 0.11 & -0.10 & 0.67 & 0.49 & 0.45 & -0.05 & -0.25 & 0.53 \\
\hline
\end{tabular}

${ }^{1}$ Absolute correlations $\leq 0.10$ were not different from zero.

${ }^{2}$ Fat $=$ milk fat content; PROT $=$ milk protein content; LACT $=$ milk lactose content; MD = milking duration; RMD = residual MD; RMDS $=\mathrm{RMD}$ including SCS; AMF = average milk flow; MMF = maximum milk flow; Time $_{\max }=$ time to MMF rate; Time $50=$ time to achieve $50 \%$ of milking yield.

milking duration, and RMD across stages of lactation for different parity animals are illustrated in Figures 1, 2, and 3, respectively. Milk yield increased with parity, with the relative difference between parities decreasing in later stages of lactation. Milking duration also increased with parity but the relative differences in milking duration between higher-parity animals was greater than observed for milk production. Moreover, the difference in milking duration between parities did not change considerably with stage of lactation, although a significant $(P<0.001)$ interaction was observed. After adjusting milking duration for differences in milk yield (i.e., RMD) the younger animals were the slowest milking in early lactation but the fastest milking in late lactation. Parity mean AMF rate (Figure 4) and MMF rate (Figure 5) across stage of lactation followed a similar pattern to each other, with first-parity animals having the lowest flow rates in early to mid lactation but the difference diminished in late lactation. The predicted probability of bimodality (Figure 6 ) was greatest in first-parity animals in early lactation but the difference between parities disappeared in later lactation.

Mean values for the different milking characteristics, with the exception of the predicted probability of bimodality, followed a very similar pattern across month of the year when milk tested. Mean values increased from January to a peak around the months of March to May, after which the mean values decreased to the period around September to October before increasing again. Spring calving (i.e., January to April) dairy production systems predominate in Ireland, likely contributing to the observed seasonal effects in milk yield and milkability traits observed in the present study. The predicted probability of bimodality across month of the year was almost directly opposite to the other milking characteristic traits, with a greater predicted probability in the months of September to November and the lowest probability in March to May.

The implications of the 2-way interactions with milking session (i.e., stage of lactation by session, parity by session, and milking order by session) were biologically small. The least squares means milk yield in the morning and evening milking was 12.09 and $8.87 \mathrm{~kg}$, respectively (SE of the difference $=0.02$ ) and this was reflected in longer least squares means milking duration in the morning (380 s) compared with the evening milking (329 s); the standard error of the difference for milking duration was $0.70 \mathrm{~s}$. However, even after accounting for differences in milk yield (i.e., RMD) the least squares means of morning milking was, on average, $10.4 \mathrm{~s}$ (SE of the difference $=0.65 \mathrm{~s}$ ) per cow longer than the evening milking. Least squares means milk flow and MMF rate was greater in the morning milking (1.94 and 5.15 $\mathrm{kg} / \mathrm{min}$, respectively) than in the evening milking (1.66 and $4.94 \mathrm{~kg} / \mathrm{min}$, respectively); the respective standard errors of the difference were 0.004 and $0.018 \mathrm{~kg} / \mathrm{min}$. The predicted probability of bimodal milking was greater in the morning milking $(23.6 \%)$ compared with the evening milking (19.8\%).

Interaction effects with milking order were generally small and of little biological importance. Mean milk yield was greatest for cows that entered early (10.50 $\mathrm{kg}$ ) or in the middle of the milking process $(10.52 \mathrm{~kg}$ ) compared with cows that were milked late $(10.44 \mathrm{~kg})$ in the milking process; the standard error of the difference was $0.017 \mathrm{~kg}$. However, after adjusting for differences among cows in milk yield, the RMD increased (i.e., milking got progressively slower) during the milking process. The mean RMD of cows milked first was -8.66 $\mathrm{s}$ compared with cows milked in the middle $(-3.00 \mathrm{~s})$ and last $(-2.35 \mathrm{~s})$. Average milk flow rate and MMF rate decreased with later entry into the milking parlor. The AMF and MMF rate of cows milked first was 1.82 


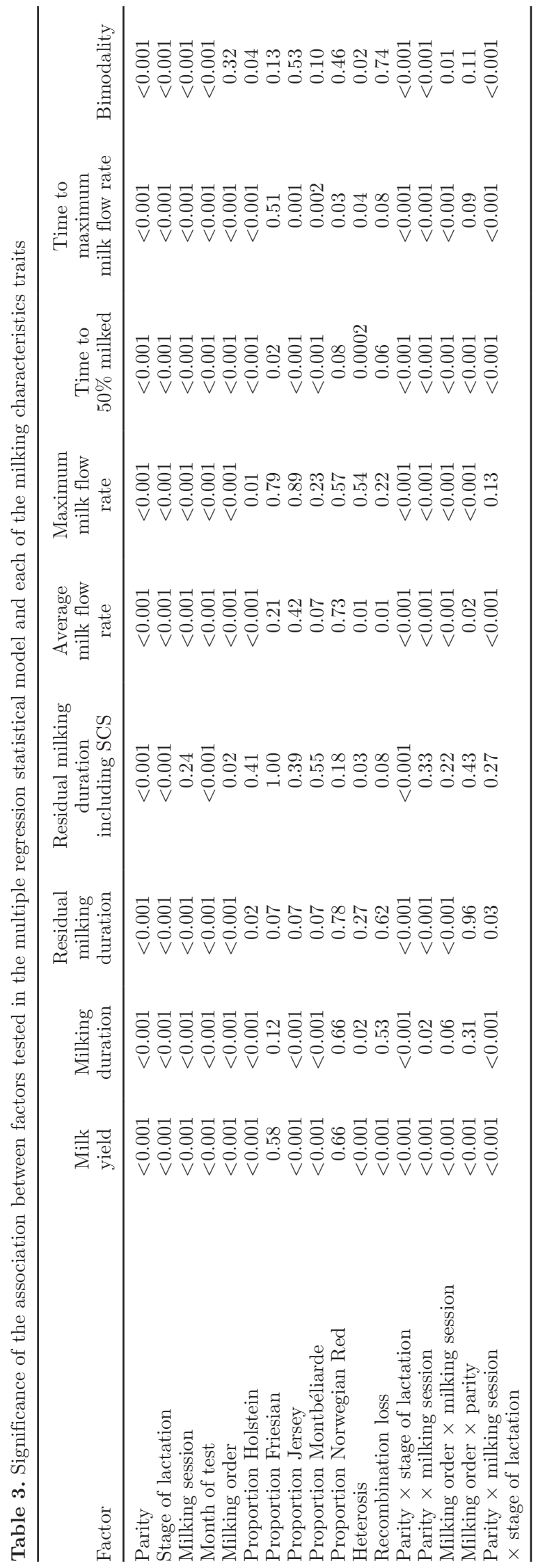

and $5.45 \mathrm{~kg} / \mathrm{min}$, respectively, compared with 1.79 and $4.82 \mathrm{~kg} / \mathrm{min}$, respectively, for cows that were milked last during the milking process.

The regression coefficients from the multiple regression models of the different milking characteristic traits on breed proportions are summarized in Table 4. Milk yield increased with Holstein proportion and Montbéliarde proportion, but decreased with proportion Jersey in the animal. Only Holstein proportion was associated with RMD, with faster milking being associated with greater Holstein proportion. The predicted probability of bimodality also increased with the Holstein proportion. The regression coefficients of both heterosis and recombination loss with the milking characteristics (Table 3) were small and in many instances were not associated with milking characteristics, with the exception of milk yield, which increased with heterosis level and level of recombination loss. Cows of $100 \%$ heterosis, on average, yielded $0.46 \mathrm{~kg}$ of milk per milking more than cows of $0 \%$ heterosis. The predicted probability of bimodality decreased from $22 \%$ in animals of $0 \%$ heterosis to $19 \%$ in animals of $100 \%$ heterosis (i.e., $14 \%$ decrease).

\section{DISCUSSION}

The objective of this study was primarily to quantify the variation in milking duration present after accounting for differences in milk yield (and SCS) and to determine what factors were associated with this novel definition of milking duration. All data originated from a 10-mo period from 1,075 herds. Nevertheless, the number of records included in the analyses was large. Results clearly show that considerable variation among animals exist in milking duration, even after accounting for differences in milk yield, which explained $23 \%$ of the variation in milking duration. Also, milking duration varied across parity and stages of lactation even when variation due to differences in milk yield was removed.

The mean milking duration (384 s) in the present study was shorter than in most previous study populations, such as a mean milking duration of $516 \mathrm{~s}$ reported in Italian Brown Swiss cattle (Gray et al. 2011) and a mean milking duration of $451 \mathrm{~s}$ in Italian HolsteinFriesian cows (Samoré et al., 2011). Zwald et al. (2005) reported a mean milking duration of only 270 s across 29 US herds. Differences in cow milk yield between studies are likely to contribute to differences among studies in milking duration. Using the (co)variance components estimated in the present study (Tables 1 and 2), the regression coefficient of milking duration on milk yield was $12.91 \mathrm{~s}$. Applying this regression coefficient to the differences in milk yield between populations accounted for almost all of the difference in mean milking duration 


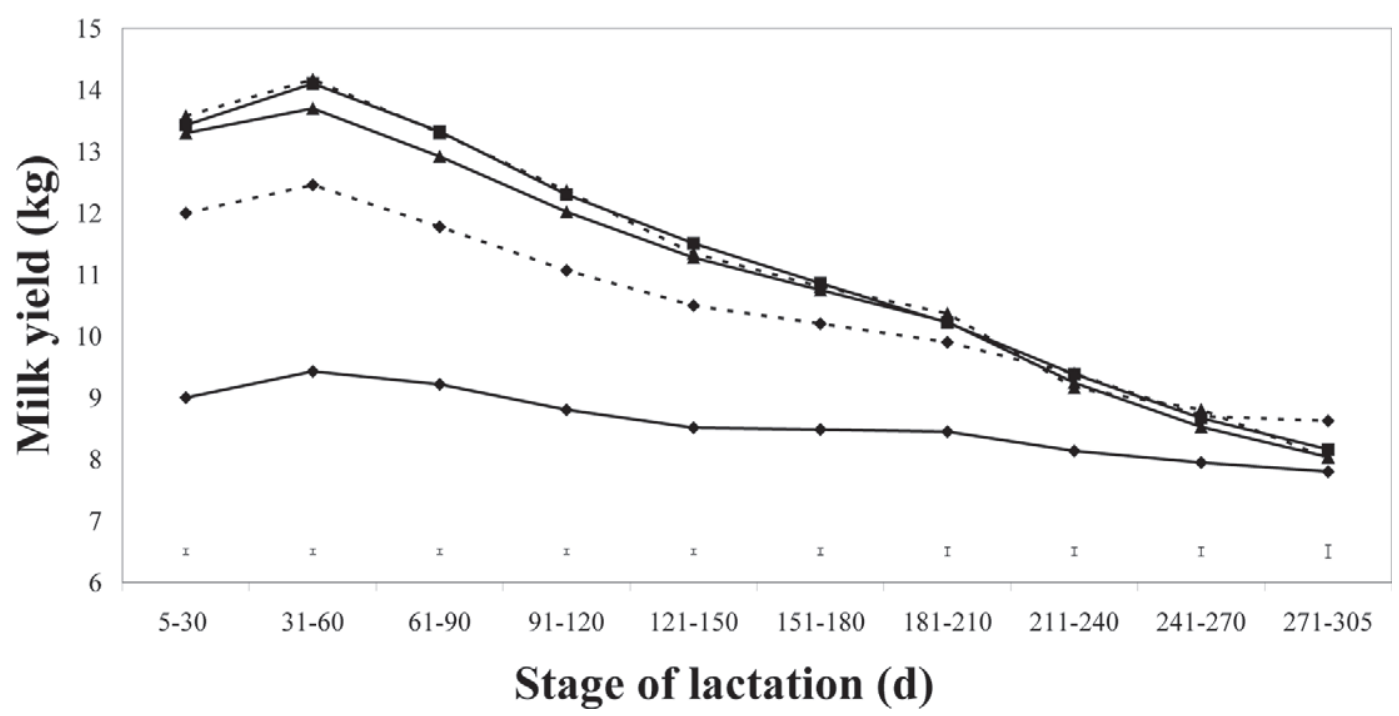

Figure 1. Least squares milk yield across stages of lactation for parity $1(--)$, parity $2(-----)$, parity $3(-\mathbf{\Delta}-)$, parity 4 (--- $\mathbf{\Delta - -})$, and parity 5 (- - ) animals. The error bars represent the mean SE across parities.

between the present study and that of Samoré et al. (2011), although it did not account for the difference in milking duration between the present study and that of Gray et al. (2011); the necessary parameters were not reported by Zwald et al. (2005). The trend of decreasing milking duration with stage of lactation after an initial rise in early lactation corroborates all previous studies (Zwald et al., 2005; Tančin et al., 2006; McCarthy et al., 2007; Walsh et al., 2007) and mimics the milk yield lactation profile (Figure 1), reflecting the positive cor- relation between milking duration and milk yield. The positive correlation between milking duration and milk yield (0.48) in the present study is expected and similar to estimates (0.32 and 0.47$)$ from other populations (Sandrucci et al., 2007; Gray et al., 2011; Samoré et al., 2011). These correlations suggest that 10 to $23 \%$ of the variation in milking duration were attributable to differences in milk yield. Using the phenotypic (co) variance matrices between milking duration, milk yield, and SCS reported in previous studies among animals

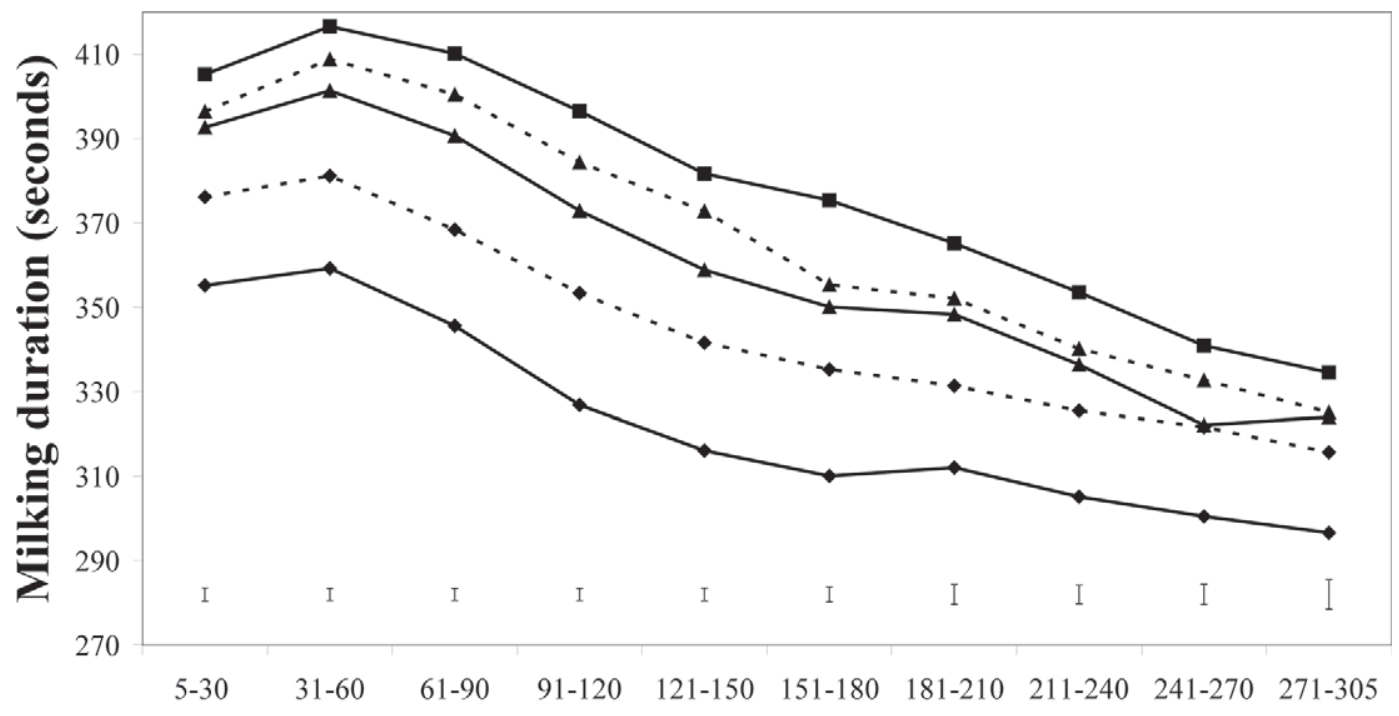

Stage of lactation (d)

Figure 2. Least squares milking duration across stages of lactation for parity $1(-\longrightarrow)$, parity $2(-----)$, parity 3 (- - - ) parity 4 (--- $\left.\mathbf{\Lambda}^{--}\right)$, and parity $5(-\mathbf{-})$ animals. The error bars represent the mean SE across parities. 


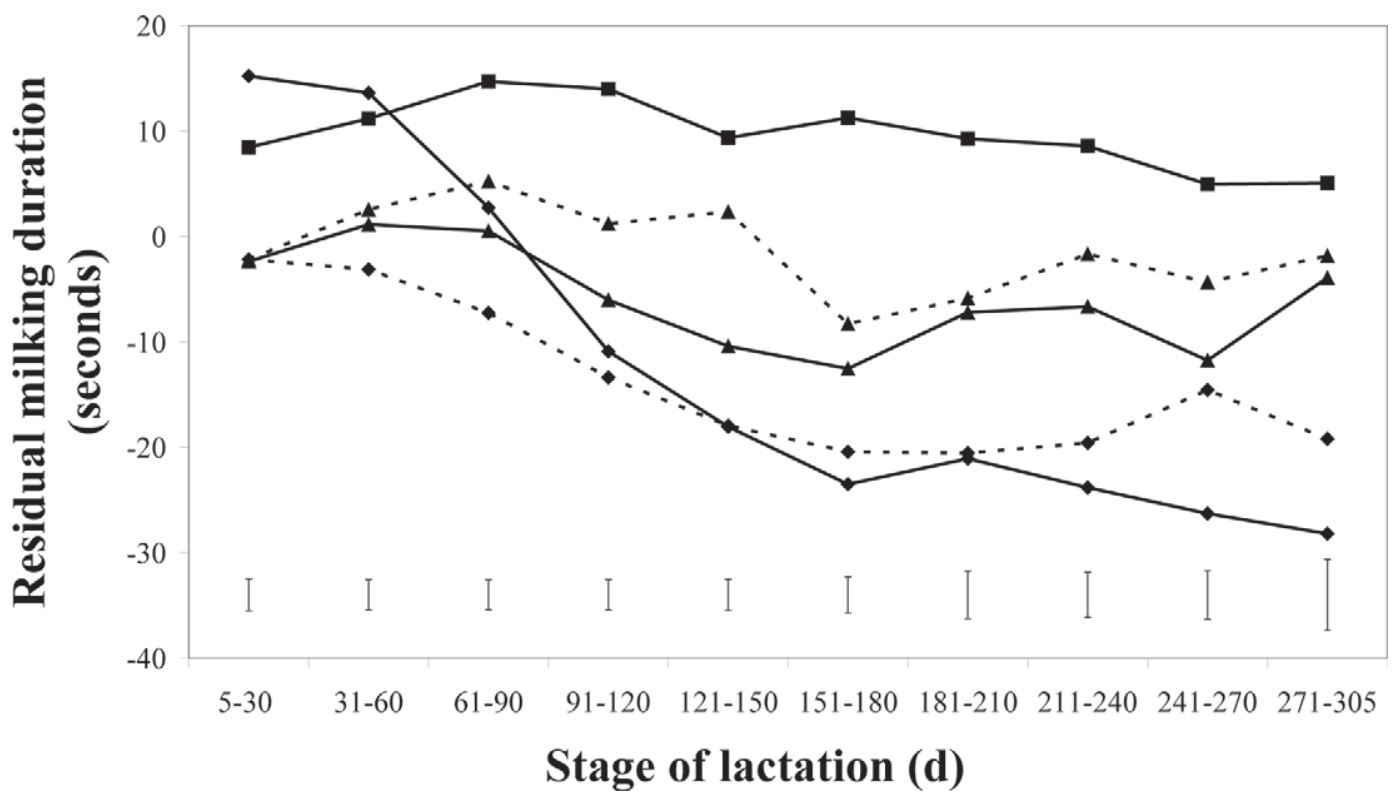

Figure 3. Least squares residual milking duration across stages of lactation for parity $1(-\downarrow-)$, parity $2(-----)$, parity $3(-\mathbf{\Lambda}-)$, parity 4 (--- $\left.\mathbf{\Lambda}_{--}\right)$, and parity 5 (- - ) animals. The error bars represent the mean SE across parities.

of only 1 breed type, the proportion of variation in milking duration explained by both milk yield and SCS varied from 10 (Gray et al., 2011) to $15 \%$ (Samoré et al., 2011), which is lower than the equivalent statistic of $24 \%$ in the present study; the standard deviation of SCS was not reported in the study of Gray et al., (2011) and was, therefore, assumed to be 2 as reported by Samoré et al., (2011) using the same SCS definition.
To our knowledge, no previous study has evaluated either RMD or RMDS as defined in the present study. These traits were defined to ensure phenotypic independence with milk yield or both milk yield and SCS, respectively (Table 2). The correlation between RMD and RMDS was almost unity due to the lack of an association between SCS and RMD and implying that the correlation between milking duration and SCS was ac-

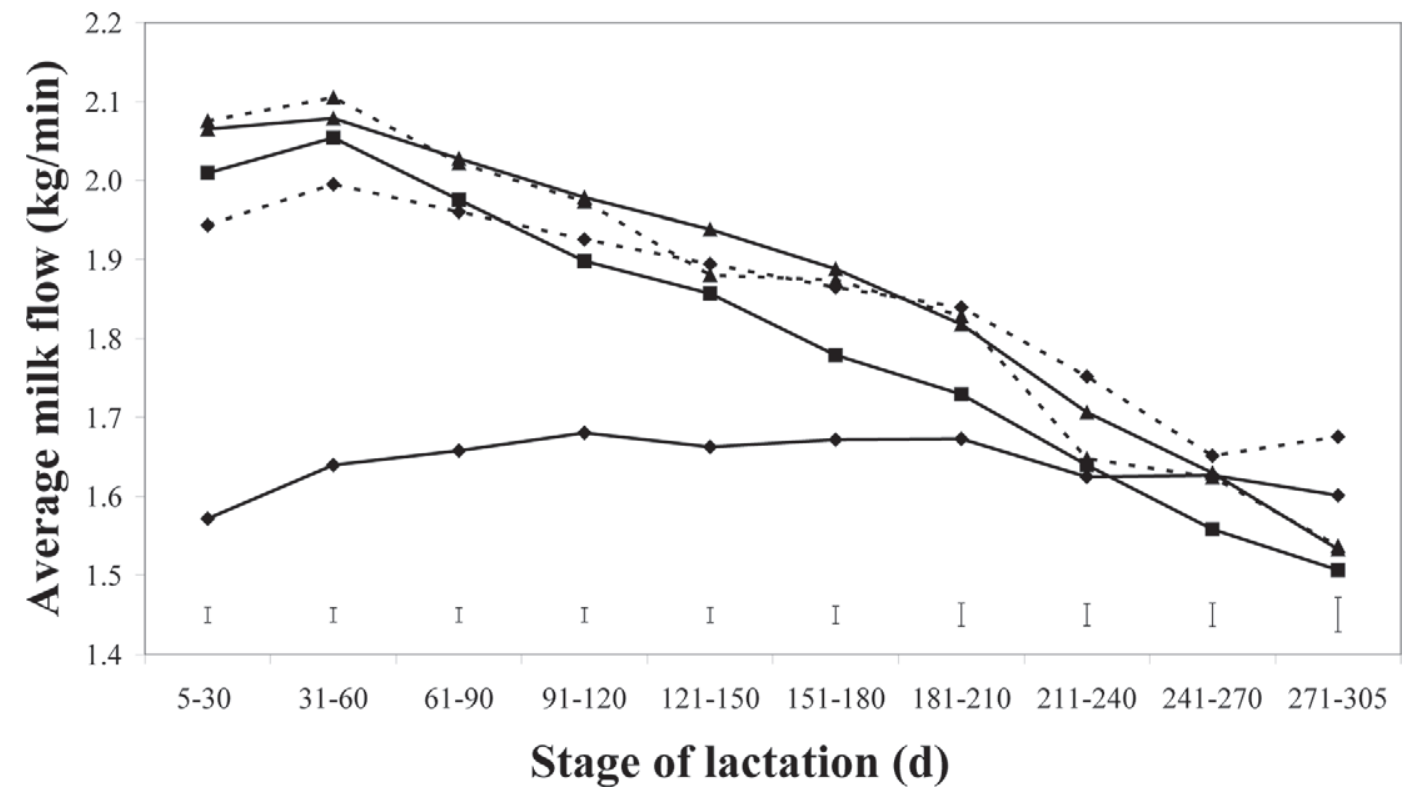

Figure 4. Least squares average milk flow rate across stages of lactation for parity $1(-\downarrow)$, parity $2(-----)$, parity $3(-\mathbf{\Delta}-)$, parity 4 $\left(--\boldsymbol{\Delta}_{---}\right)$, and parity 5 (- - ) animals. The error bars represent the mean SE across parities. 


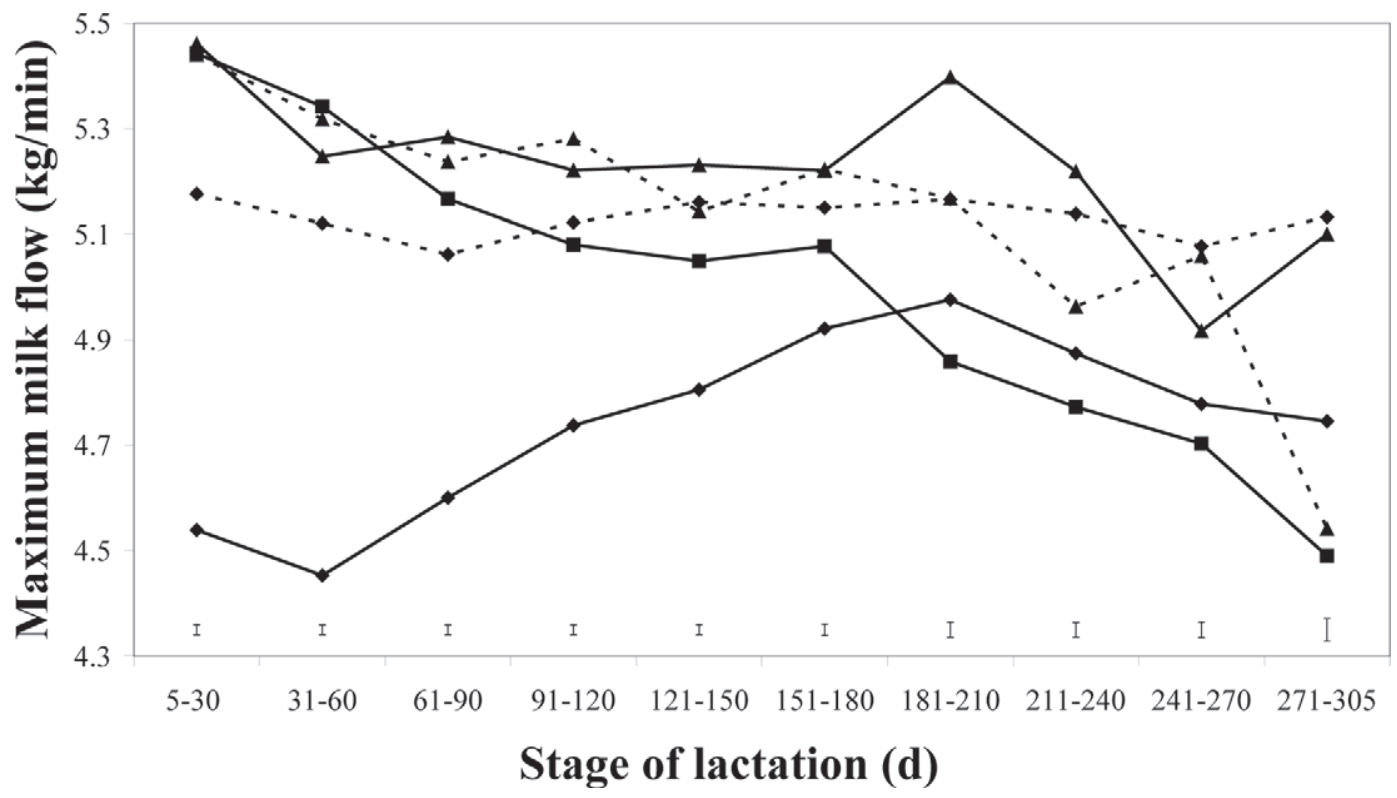

Figure 5. Least squares maximum milk flow rate across stages of lactation for parity $1(-\downarrow-)$, parity $2(-----)$, parity $3(-\mathbf{\Delta}-)$, parity 4 (--- $\left.\mathbf{\Lambda}_{--}\right)$, and parity 5 (- - ) animals. The error bars represent the mean SE across parities.

counted for by adjustment of milking duration for milk yield. However, this lack of a correlation may not be true in other populations and should, therefore, be investigated within individual populations. Considerable variation in both RMD and RMDS existed, indicating large variation in milking duration independent of milk yield (and SCS). This is a potentially useful trait for quantifying the genetic merit of animals that milk for longer duration irrespective of milk yield (Berry et al., 2013). Evaluation of RMD and milking duration at the parity level clearly shows reranking of parities and, therefore, RMD is arguably a superior measure of milking efficiency. Although AMF rate, which could be used as a measure of milking efficiency, was correlated with both RMD and RMDS, the correlations were less than unity ( -0.75 to -0.74$)$, suggesting that not all varia-

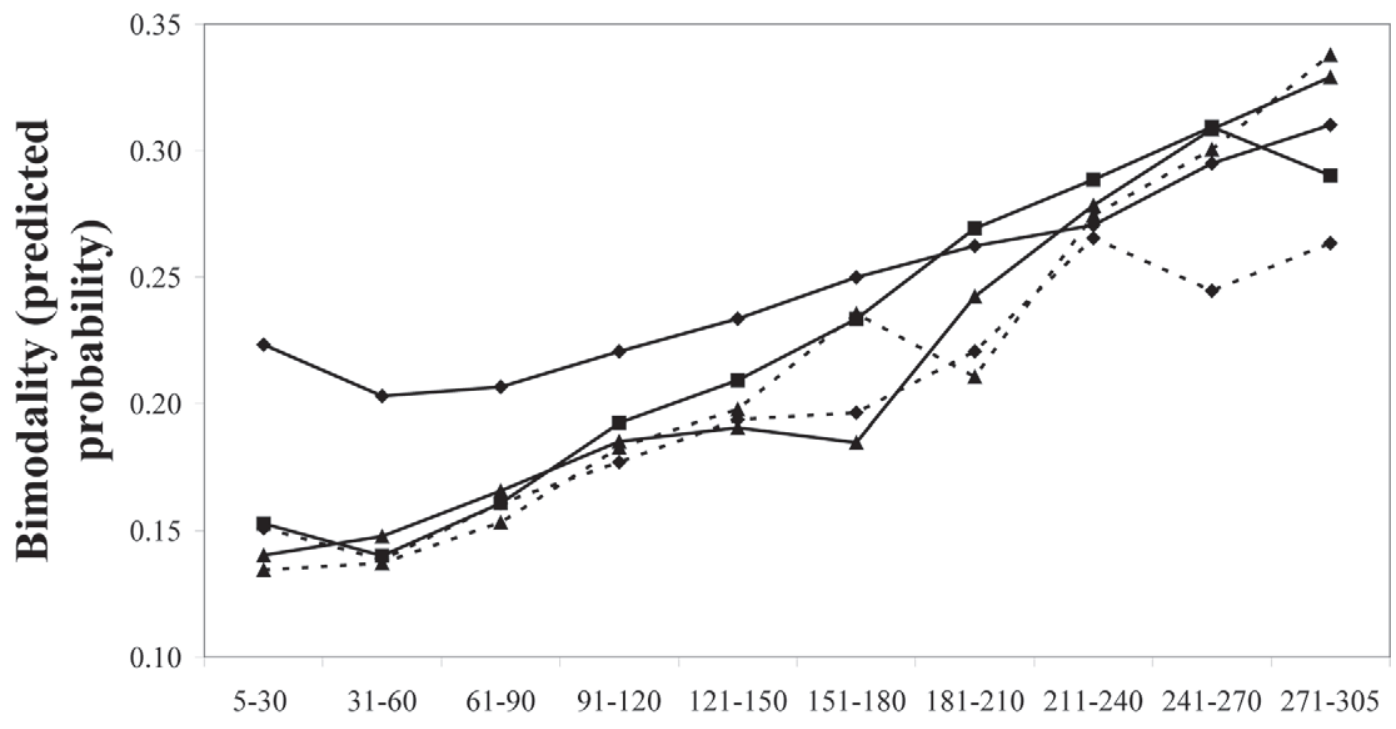

\section{Stage of lactation (d)}

Figure 6. Predicted probability for bimodality rate across stages of lactation for parity $1(-\downarrow)$, parity $2(-----)$, parity $3(-\mathbf{\Delta}-)$, parity $4(--\mathbf{\Lambda - -})$, and parity $5(-\mathbf{-})$ animals. 
tion in RMD or RMDS was explained by differences in AMF rate. The mathematical calculation of AMF rate and RMD or RMDS are analogous to the feed efficiency variables of feed conversion ratio and residual feed intake or residual daily gain, respectively (Crowley et al., 2010); Crowley et al. (2010) reported absolute phenotypic correlations with feed conversion ratio in growing bulls of 0.41 to 0.71 for residual feed intake or residual daily gain, respectively. However, the latter traits, based also on residuals from a multiple regression model, are preferred because of their phenotypic independence with the regressor variables (Crowley et al., 2010), whereas the trait feed conversion ratio is associated with both the numerator and denominator. Nonetheless, phenotypic independence does not necessarily imply genetic independence (Kennedy et al., 1993) and the genetic correlations between both RMD and RMDS with other performance traits, in particular milk yield and SCS, should be quantified.

The weak correlation $(-0.05)$ between milking duration and SCS in the present study is consistent with previous studies in Italian Holstein-Friesian dairy cows (-0.05; Samoré et al., 2011) and Italian Brown Swiss cows (-0.02; Gray et al., 2011) as well as in Irish dairy cows of alternative breeds $(-0.09$; Prendiville et al., $2010)$ and Croatian Holstein-Friesian cows ( -0.08 ; Mijić et al., 2004). Weak phenotypic correlations (0.02 to 0.06 ) have also been reported between SCS and subjectively scored milking speed (Boettcher et al., 1998); for the subjective measures of milking speed, a higher phenotypic value reflects faster milking. Irrespective of the definition of milking duration or milking speed, most studies appear to agree that faster-milking animals have greater SCS, which may be due to decreased tension of the teat sphincter muscle, thereby providing a weaker barrier to infection. Corroborating the weak correlations between both AMF and MMF rate with SCS in the present study ( -0.08 to 0.01$)$, weak correlations $(-0.03$ to 0.13$)$ were also reported between the flow rate traits and SCS in other dairy cow populations (Mijić et al., 2004; Prendiville et al., 2010; Gray et al., 2011; Samoré et al., 2011). Grindal and Hillerton (1991) reported greater mastitis incidence in quarters with greater milk peak flow rates. Information is lacking in the scientific literature on the phenotypic correlation between milk duration and milk composition. Weak correlations between milking duration and milk composition existed in the present study.

The lactation profiles for the different milking characteristics are generally in line with previous studies in lactating dairy cows (Zwald et al., 2005; Tančin et al., 2006; McCarthy et al., 2007; Walsh et al., 2007; Dodenhoff and Emmerling, 2009; Prendiville et al. 2010); Samoré et al. (2011) also reported an increased 
percentage of bimodal milk profiles later in lactation. Furthermore, the greater milking duration in older animals reported in the present study corroborate analyses of other international populations (Tančin et al., 2006; McCarthy et al., 2007; Sandrucci et al., 2007; Walsh et al., 2007). Adjustment of milking duration for milk yield (i.e., RMD) showed that younger animals were, on average, the faster-milking animals in the latter stages of lactation. The RMD lactation profile of the younger animals differed from older animals, with the speed of milking in younger animals increasing with stage of lactation, possibly reflecting the acclimatization of younger animals to the milking process. In contrast, however, to the present study, others (Tančin et al., 2006; Antalík and Strapák, 2011) detected no significant parity effects on either AMF or MMF rate; some studies (McCarthy et al., 2007; Sandrucci et al., 2007; Walsh et al., 2007; Dodenhoff and Emmerling, 2009) did nonetheless report a significant effect of parity on AMF and MMF rate, with mean parity trends in agreement with those observed in the present study.

The mean incidence of bimodality in the present study (16\%) was lower than reported elsewhere $(35 \%$ in Sandrucci et al., 2007; 27\% in Antalík and Strapák, 2011; 33.8\% in Samoré et al., 2011). This could be due to a greater extent of udder preparation or stimulation of cows in the commercial herds represented in the present study but could also be due to a different genetic makeup of animals in the present study based on grazed grass systems of milk production compared with other studies that were primarily based on confinement systems of milk production. Bimodality is moderate to highly heritable (0.43; Samoré et al., 2011), suggesting that the latter is a plausible reason.

The greater milking duration, AMF rate, and MMF rate in the morning milking compared with the evening milking in cows milked twice daily is in agreement with a study of 38 Dutch Holstein cows (Tančin et al., 2006). Tančin et al. (2006) speculated that the greater milking duration in the morning milking was due to the greater yields in the morning milking because of the greater time duration between evening and morning milking. This hypothesis was, however, not confirmed in the present study, as after accounting for differences in milk yield (i.e., RMD), milking duration in the morning milking was still of longer duration. Differences may be partly due to differences in milk composition in the a.m. and p.m. milking.

No previous study has attempted to relate milking rank order (i.e., the order in which the animals enter the milking parlor) to milking characteristics. Using correlation analysis and a data set overlapping with the data used in the present study, Berry and McCarthy (2012) reported a positive correlation between milking rank and milk yield (i.e., first-milked animals had, on average, higher yields), which is in general agreement with the present study. The present study highlighted that although the cows that entered the parlor early in the milking process had greater yields, after accounting for the differences in yields (and other fixed effects such as parity), they were faster milkers.

\section{CONCLUSIONS}

Both RMD and RMDS exhibit considerable variation and are both phenotypically independent of milk yield, with RMDS also being independent of SCS. However the correlation between RMD and RMDS in the present study was almost unity, suggesting little advantage of including SCS in the regression; this lack of association, however, may not be true in other populations and should therefore be investigated. Furthermore, in the present study, milking duration was regressed on milk yield and SCS but other measures, such as milk solids yield, could also be used in the multiple regression model. The novel milkability traits defined here could also be useful traits in breeding programs. A decision support tool that uses RMD or RMDS after adjustment for systematic environmental effects could be useful for producers to more accurately identify animals with poorer milking efficiency.

\section{REFERENCES}

Antalík, P., and P. Strapák. 2011. Effect of parity and lactation stage on milk flow characteristics of Slovak Simmental dairy cows. Vet. Med. Zoot. 54:8-13.

Berry, D. P., F. Buckley, P. G. Dillon, R. D. Evans, and R. F. Veerkamp. 2004. Genetic relationships among linear type traits, milk yield, body weight, fertility and somatic cell count in primiparous dairy cows. Ir. J. Agric. Food Res. 43:161-176.

Berry, D. P., M. Burke, M. O'Keeffe, and P. O'Connor. 2006. Do-ityourself milk recording as a viable alternative to supervised milk recording in Ireland. Ir. J. Agric. Food Res. 45:1-12.

Berry, D. P., J. Coyne, B. Coughlan, M. Burke, J. McCarthy, A. R Cromie, and S. McParland. 2013. Development of a new management sub-index for the Irish dairy cattle economic breeding index. Proc. Agric. Res. Forum, Tullamore, Ireland.

Berry, D. P., B. L. Harris, A. M. Winkelman, and W. Montgomerie. 2005. Phenotypic associations between traits other than production and longevity in New Zealand dairy cattle. J. Dairy Sci. 88:2962-2974.

Berry, D. P., and J. McCarthy. 2012. Genetic and non-genetic factors associated with milking order in lactating dairy cows. Appl. Anim. Behav. Sci. 136:15-19.

Boettcher, P. J., J. C. M. Dekkers, and B. W. Kolstad. 1998. Development of an udder health index for sire selection based on somatic cell score, udder conformation, and milking speed. J. Dairy Sci. 81:1157-1168.

Brown, C. A., S. J. Rischette, and L. H. Schultz. 1986. Relationship of milking rate to somatic cell count. J. Dairy Sci. 69:850-854.

Crowley, J. J., M. McGee, D. A. Kenny, D. H. Crews Jr., R. D. Evans, and D. P. Berry. 2010. Phenotypic and genetic parameters for different measures of feed efficiency in different breeds of Irish performance-tested beef bulls. J. Anim. Sci. 88:885-894. 
Dodenhoff, J., and R. Emmerling. 2009. Genetic parameters for milkability from the first three lactations in Fleckvieh cows. Animal 3:329-335.

Dzidic, A., J. Macuhova, and R. M. Bruckmaier. 2004. Effects of cleaning duration and water temperature on oxytocin release and milk removal in an automatic milking system. J. Dairy Sci. 87:41634169.

Gilmour A.R., B.J. Gogel, B.R. Cullis and R. Thompson. 2009. ASReml User Guide. Release 3.0. VSN International Ltd., Hemel Hempstead, UK.

Gray, K. A., F. Vacirca, A. Bagnato, A. B. Samoré, A. Rossoni, and C. Maltecca. 2011. Genetic evaluations for measures of the milkflow curve in the Italian Brown Swiss population. J. Dairy Sci. 94:960-970.

Grindal, R. J., and J. E. Hillerton. 1991. Influence of milk flow rate on new intramammary infection in dairy cows. J. Dairy Res. 58:263-268.

Jago, J. G., and D. P. Berry. 2011. Associations between herd size, rate of expansion and production, breeding policy and reproduction in spring-calving dairy herds. Animal 5:1626-1633.

Kennedy, B. W., J. H. van der Werf, and T. H. E. Meuwissen. 1993. Genetic and statistical properties of residual feed intake. J. Anim. Sci. 71:3239-3250.

Krogmeier, D., B. Luntz, and K.-U. Goetz. 2006. Investigations on the economical value of type traits on the basis of auction sales of first lactation Brown Swiss and Simmental cows. Züchtungskunde 78:464-478.

McCarthy, S., D. P. Berry, P. G. Dillon, M. Rath, and B. Horan. 2007. Effect of strain of Holstein-Friesian and feed system on udder health and milking characteristics. Livest. Sci. 107:19-28.

Mijić, P., I. Knežević, and M. Domaćinović. 2004. Connection of milk flow curve to the somatic cell count in bovine milk. Arch. Tierzucht 6:551-556.

Prendiville, R., K. M. Pierce, and F. Buckley. 2010. A comparison between Holstein-Friesian and Jersey dairy cows and their F1 cross with regard to milk yield, somatic cell score, mastitis, and milking characteristics under grazing conditions. J. Dairy Sci 93:2741-2750

Prints, D. 2002. Economic value of milkability in dairy cattle. MS Thesis. Animal Breeding and Genetics Group of the Wageningen Institute of Animal Sciences, Wageningen University, Wageningen, the Netherlands.

Samoré, A. B., S. I. Román-Ponce, F. Vacirca, E. Frigo, F. Canavesi, A. Bagnato, and C. Maltecca. 2011. Bimodality and the genetics of milk flow traits in the Italian Holstein-Friesian breed. J. Dairy Sci. 94:4081-4089.

Sandrucci, A., A. Tamburini, L. Bava, and M. Zucali. 2007. Factors affecting milk flow traits in dairy cows: Results from a field study. J. Dairy Sci. 90:1159-1167.

SAS Institute. 2011. User's Guide. Version 9.1.0 edition. SAS Institute Inc., Cary, NC.

Sivarajasingam, S., E. B. Burnside, J. W. Wilton, W. C. Pfeiffer, and D. G. Grieve. 1984. Ranking dairy sires by linear programming dairy farm models. J. Dairy Sci. 67:3015-3024.

Tančin, V., A. H. Ipema, and P. Hogewerf. 2007. Interaction of somatic cell count and quarter milk flow patterns. J. Dairy Sci. 90:2223-2228

Tančin, V., A. H. Ipema, P. Hogewerf, and J. Mačuhová. 2006. Sources of variation in milk flow characteristics at udder and quarter levels. J. Dairy Sci. 89:978-988.

Walsh, S., F. Buckley, D. P. Berry, M. Rath, K. Pierce, N. Byrne, and P. Dillon. 2007. Effects of breed, feeding system, and parity on udder health and milking characteristics. J. Dairy Sci. 90:5767-5779

Zwald, N. R., K. A. Weigel, Y. M. Chang, R. D. Welper, and J. S. Clay. 2005. Genetic evaluation of dairy sires for milking duration using electronically recorded milking times of their daughters. J. Dairy Sci. 88:1192-1198. 